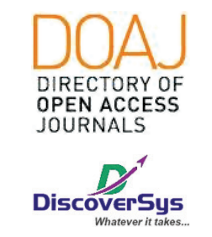

Published by DiscoverSys

\section{Karakteristik kasus otitis eksterna di RSUP Sanglah Denpasar periode April 2015-April 2016}

\author{
N.P Mirah Ayunda Kartika Wulandari, ${ }^{1 *}$ I Made Sudipta²
}

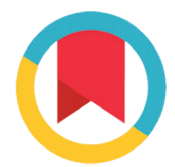

CrossMark

\title{
ABSTRACT
}

Background: External Otitis (OE) is one of the most common cases in ENT. There are an estimated 8.1 visits with an $0 \mathrm{E}$ diagnosis per 1,000 annually. The low understanding of the community about $\mathrm{OE}$ caused the cases to become frequent. This study aims to increase public understanding of $\mathrm{OE}$ by knowing the characteristics of $\mathrm{OE}$ in Sanglah Hospital.

Methods: A study with descriptive cross sectional method. Samples were taken from Sanglah Hospital's medical record data on period 2015-2016 with total sampling method.

Results: A total of 84 samples were successfully analyzed, and found: OE was most common in the $15-49$ years age group (55.9\%). Gender dominating is female (52.4\%). The most clinical symptoms of $\mathrm{OE}$ patients were ear pain (67.9\%), followed by ear discharge (55.9\%), ear that felt full (22.6\%), itchiness (20.2\%), ringing (21.4\%), hearing loss (15.5\%), and accompanied (4.8\%). The most frequent cause of $\mathrm{OE}$ is due to trauma (58.3\%), followed by fungi or bacterial infection (20.3\%), combined causes (11.9\%), and the least caused by systemic disease (9.5\%).

Conclusions: The OE case at Sanglah Hospital is most commonly found in the female population, age group 15-49 years, with the most common symptom of earache and caused by mechanical trauma.

Keywords: otitis external, cause, age, clinical symptoms.

Cite This Article: Wulandari, N.P.M.A.K., Sudipta, I.M. 2020. Karakteristik kasus otitis eksterna di RSUP Sanglah Denpasar periode April 2015April 2016. Intisari Sains Medis 11(2): 489-492. D0l: 10.15562/ism.v11i2.619

\section{ABSTRAK}

Latar Belakang: Otitis Eksternal (OE) merupakan salah satu kasus yang sering ditemukan dalam bidang THT. Diperkirakan terdapat 8.1 kunjungan dengan diagnosis OE per 1.000 per tahunnya. Rendahnya pemahaman masyarakat mengenai $\mathrm{OE}$ menyebabkan kasus ini menjadi sering terjadi. Studi ini bertujuan untuk meningkatkan pemahaman masyarakat mengenai $\mathrm{OE}$ dengan mengetahui gambaran kejadian OE di RSUP Sanglah.

Metode: Sebuah studi dengan metode deskriptif potong lintang. Sampel diambil dari data rekam medis RSUP Sanglah pada periode 2015-2016 dengan metode total sampling.

Hasil: Sebanyak 84 sampel berhasil di analisis, dan ditemukan: OE paling sering terjadi pada kelompok umur $15-49$ tahun, $(55,9 \%)$. Jenis kelamin yang mendominasi adalah perempuan (52,4\%). Gejala klinis penderita $\mathrm{OE}$ terbanyak adalah nyeri telinga $(67,9 \%)$, diikuti berair atau keluar cairan dari telinga $(55,9 \%)$, terasa penuh $(22,6 \%)$, rasa gatal $(20,2 \%)$, berdenging (21,4\%), gangguan pendengaran (15,5\%), dan yang disertai $(4,8 \%)$. Penyebab OE terbanyak adalah karena trauma $(58,3 \%)$, diikuti karena jamur atau bakteri $(20,3 \%)$, penyebab gabungan $(11,9 \%)$, dan paling sedikit disebabkan oleh penyakit sistemis (9,5\%).

Simpulan: Kasus OE di RSUP Sanglah paling sering ditemui pada populasi wanita, kelompok umur 15-49 tahun, dengan gejala tersering berupa nyeri telinga dan disebabkan oleh trauma mekanis.
1Program Studi Pendidikan Dokter, Fakultas Kedokteran Universitas Udayana

${ }^{2}$ Department IImu Penyakit Telinga Hidung Tenggorokan-KepalaLeher (THT-KL) RSUP Sanglah Universitas Udayana

*Correspondence to:

N.P Mirah Ayunda Kartika Wulandari, Program Studi Pendidikan Dokter, Fakultas Kedokteran Universitas Udayana

wulancontagious@yahoo.co.id

Diterima: 14-09-2019

Disetujui: $10-07-2020$

Diterbitkan: 01-08-2020

Kata kunci: otitis eksterna, penyebab, umur, gejala klinis.

Cite Pasal Ini: Wulandari, N.P.M.A.K., Sudipta, I.M. 2020. Karakteristik kasus otitis eksterna di RSUP Sanglah Denpasar periode April 2015April 2016. Intisari Sains Medis 11(2): 489-492. D0l: 10.15562/ism.v11i2.619

\section{PENDAHULUAN}

Otitis eksterna adalah suatu proses peradangan yang dapat disebabkan oleh berbagai hal, dan kebanyakan disebabkan oleh infeksi pada kanalis auditorius eksternal dan atau daun telinga. ${ }^{1} \mathrm{OE}$ diklasifikasikan berdasarkan onset gejala menjadi OE akut dimana gejala yang dialami terjadi di bawah 6 minggu dan kronis apabila gejala yang dirasakan sudah berlangsung lebih dari 3 bulan, dan nekrosis yang merupakan bentuk ganas.
Otitis eksterna diperkirakan mengenai 10\% orang pada tahap tertentu. ${ }^{2}$ Data yang tercatat pada tahun 2007 menunjukkan setidaknya terdapat 2,4 juta orang (8,1 kunjungan per 1.000 penduduk) di Amerika Serikat yang didiagnosis OE akut. (Piercefield dkk., 2011). Sekitar 98\% disebabkan oleh bakteri, terutama Pseudomonas aeruginosa (20\%-60\%) dan Staphylococcus aureus $(10 \%-70 \%)^{2}$ 
Otitis eksterna dapat terjadi karena dipengaruhi oleh beberapa faktor. Secara anatomis sendiri, adanya lekukan pada liang telinga dan suasana lembap pada liang telinga dapat menyebabkan laserasi dari kulit. Berenang, mandi, cuaca yang panas dan lembap menyebabkan suasana liang telinga menjadi semakin sesuai untuk pertumbuhan bakteri yang dapat masuk ke laserasi telinga melalui media air. ${ }^{1,2}$ Faktor yang tak kalah sering dalam menyebabkan $\mathrm{OE}$ adalah trauma pada liang telinga yang diakibatkan dari pembersihan telinga dengan alat yang salah, cara yang salah maupun terlalu sering dalam membersihkan telinga. Hal ini akan memicu invasi bakteri kedalam kulit yang rusak. Selain itu masuknya air atau bahan iritan dapat menyebabkan otitis eksterna. Infeksi yang berkembang di liang telinga mengaktivasi respon inflamasi, edema dan pembengkakan liang telinga. Metabolisme bakteri yang membuat koloni pada liang telinga dapat menyebabkan eksudat dan pus dapat terproduksi di liang telinga. Apabila terlambat ditangani, kondisi ini dapat bertambah berat dan infeksi dapat meluas hingga ke wajah dan leher. Pasien dengan status imunokompromais dan mendapatkan radioterapi pada daerah kepala seringkali mendapat komplikasi berupa bentuk maligna dari $\mathrm{OE}$ meskipun $\mathrm{OE}$ sudah ditangani secara adekuat. Dikatakan maligna karena pada kondisi ini bakteri akan menginvasi jaringan lunak yang lebih dalam dan menyebabkan oeteomielitis pada tulang temporal. Osteomyelitis pada tulang temporal meningkatkan risiko penyebaran infeksi ke organ yang lebih vital seperti otak dan selaputnya. ${ }^{3,4}$

Diagnosis dapat ditegakkan berdasarkan adanya keluhan dari penderita berupa nyeri hebat pada telinga terutama saat mengunyah, menekan tragus dan menggerakan daun telinga, telinga berair, telinga yang gatal, maupun adanya keluhan penurunan pendengaran. Pemeriksaan fisik telinga dilakukan untuk mengonfirmasi adanya OE. Biasanya dapat dilihat adanya liang telinga yang kemerahan dan edema. Gambaran serupa dapat ditemukan pada liang telinga luar dan jaringan lunak periaurikuler. Dapat ditemukan adanya kekakuan pada jaringan lunak pada ramus mandibula dan mastoid. Membran timpani biasanya intak dan demam jarang terjadi. ${ }^{2,3}$ Untuk memastikan jenis patogen yang menginfeksi dan menentukan antimikroba yang sesuai, dapat dilakukan kultur sekret telinga serta uji sensitivitas dari hasil biakan.

Prinsip tatalaksana pada semua tipe otitis eksterna adalah dengan membersihkan liang telinga, menilai sekret, edema dinding kanalis, dan membran timpani untuk memutuskan penggunaan tampon untuk mengoleskan obat, dan pendekatan farmakologi dengan pemberian antibiotika oral. ${ }^{1,2}$
Secara umum prognostis dari OE adalah baik jika mendapatkan penanganan yang sesuai. Bila tidak ditangani dengan baik dapat menyebabkan kekambuhan dan komplikasi seperti maligna otitis eksterna. ${ }^{1,2}$

Sering kali masyarakat belum mengenal OE dan mengetahui bahaya dari tidak bersihnya telinga, cuaca dan pola pembersihan telinga. Terkadang pada beberapa orang di masyarakat membersihkan telinga sampai menyebabkan trauma ringan pada telinganya. Maka dari itu perlu adanya pemahaman tentang hal tersebut. Studi ini bertujuan untuk mengetahui gambaran kejadian otitis eksterna di RSUP Sanglah.

\section{METODE}

Penelitian ini menggunakan rancangan penelitian observational deskriptif dengan pendekatan crosssectional. Populasi sampel yang digunakan adalah semua pasien OE di Bagian THT-KL RSUP Sanglah Denpasar selama Januari 2015 - Desember 2016. Sampel diambil dengan metode total sampling dimana berapa pun data yang tersedia dan dapat diakses itulah yang digunakan. Variabel yang dicari dari rekam medis berupa umur saat terdiagnosis, jenis kelamin, gejala klinis, dan penyebab $\mathrm{OE}$ Penelitian ini dilakukan di Bagian THT-KL RSUP Sanglah Denpasar mulai dari April sampai Juli 2016 dengan mengambil data pasien kanker paru yang tercatat pada bulan Januari 2015 - Desember 2016. Data yang terkumpul kemudian dicatat dan diolah melalui tahap cleaning (melakukan pembersihan data), editing (menyunting data), coding (membuat lembaran kode), dan entrying (memasukkan data ke dalam tabel). Peneliti kemudian menggunakan software SPSS 21.0 untuk menganalisis data yang telah dikumpulkan secara statistik deskriptif. Hasil pencatatan akan disajikan dalam bentuk tabel distribusi frekuensi.

\section{HASIL}

Dari tahun 2015-2016 terdaftar 84 kasus OE. Sebagian besar pasien adalah perempuan (52,4\%). Sedangkan laki-laki yang menderita $\mathrm{OE}$ adalah sebesar $47,6 \%$. Sebagian besar pasien berasal dari kelompok umur 15-49 tahun (55,9\%), disusul oleh kelompok umur di atas 50 tahun $(22,6 \%)$ dan kelompok umur 0-14 tahun (21,5\%). Gejala yang paling banyak ditemui adalah nyeri pada telinga $(67,9 \%)$, disusul oleh telinga berair $(55,9 \%)$, telinga terasa penuh $(22,6 \%)$, sensasi berdenging $(21,4 \%)$, gangguan pendengaran $(15,5 \%)$ dan hanya sedikit yang mengaku mengalami demam selama menderita OE (4,9\%). Penyebab tersering dari OE adalah trauma $(58,3 \%)$ disusul oleh infeksi 
Tabel 1 Karakteristik Pasien dengan Otitis Eksterna di RSUP Sanglah periode 2015-2016

\begin{tabular}{llcc}
\hline Variabel & & $\mathbf{F}$ & $\mathbf{( \% )}$ \\
\hline Jenis Kelamin & Laki-Laki & 40 & 47,6 \\
& Perempuan & 44 & 52,4 \\
Usia & $0-14$ th & 18 & 21,5 \\
& $15-49$ th & 47 & 55,9 \\
Gejala Klinis & $>50$ th & 19 & 22,6 \\
& Berdenging & 18 & 21,4 \\
& Berair & 47 & 55,9 \\
& Terasa Penuh & 19 & 22,6 \\
& Nyeri & 57 & 67,9 \\
& Gatal & 17 & 20,2 \\
& Gangguan Dengar & 13 & 15,5 \\
Penyebab & Demam & 4 & 4,8 \\
& Trauma & 49 & 58,3 \\
& Jamur/Bakteri & 17 & 20,3 \\
& Penyakit Sistemis & 8 & 9,5 \\
& $>1$ Penyebab & 10 & 11,9 \\
\hline
\end{tabular}

jamur atau bakteri (20,3\%), penyakit sistemis yang menurunkan sistem imunitas (11,9\%) dan 9,5\% disebabkan oleh lebih dari 1 penyebab.

\section{PEMBAHASAN}

Otitis eksterna merupakan salah satu keluhan otologi yang paling sering dijumpai pada bidang THT. Beberapa peneliti sebelumnya telah melakukan studi serupa mengenai OE. Pada penelitian ini ditemukan jumlah penderita perempuan lebih banyak dari laki-laki. Studi dari Kaimio dkk juga mengungkapkan bahwa kebanyakan pasien $\mathrm{OE}$ ditemukan berjenis kelamin perempuan. ${ }^{4}$ Studi dari Abdullahi juga mendukung hasil ini dimana 63,6\% dari penderita OE merupakan perempuan. ${ }^{5}$ Perbedaan prevalensi OE pada jenis kelamin lakilaki dan perempuan diperkirakan terjadi karena adanya perbedaan karakteristik kanal telinga pada perempuan dan laki-laki. Liang telinga lakilaki secara konsisten dinyatakan lebih panjang dibandingkan dengan perempuan. Liang telinga perempuan juga lebih sempit dan berbentuk oval. Kondisi anatomis liang telinga perempuan yang lebih pendek dan sempit memberikan risiko untuk terjadi infeksi lebih sering dibandingkan dengan laki-laki. ${ }^{6}$ Wanita juga dikaitkan dengan perilaku yang terlalu sering melakukan pembersihan telinga sehingga meningkatkan predisposisi untuk terkena OE. ${ }^{6,7}$ Namun, studi dari Musa dkk yang menunjukkan hasil yang berbeda yaitu 60,9\% dari penderita OE adalah laki-laki. Pada studi ini tidak dijelaskan alasan prevalensi laki-laki lebih banyak. ${ }^{7,8}$ Perbedaan proporsi berdasarkan jenis kelamin juga dapat dipengaruhi oleh perbandingan jumlah laki-laki dan perempuan pada suatu populasi. Apabila jumlah salah satu jenis kelamin memang jauh lebih banyak pada populasi tersebut, maka memungkinkan proporsi OE berdasarkan jenis kelamin nampak cenderung di dominasi oleh jenis kelamin tersebut.

Kelompok usia terbanyak pada penelitian ini adalah 15-49 tahun. Hasil ini bersesuaian dengan studi dari Musa dkk. dimana sebagian besar dari kasus $\mathrm{OE}(58,6 \%)$ diderita oleh remaja-dewasa muda dari usia 16 tahun - 30 tahun. Kelompok usia ini dikaitkan dengan kebiasaan mereka untuk melakukan pembersihan telinga secara berlebihan dan dengan cara yang lebih kasar dibandingkan dengan kelompok usia lain sehingga menimbulkan peningkatan risiko trauma liang telinga akibat pembersihan telinga. ${ }^{4,5,8}$

Gejala klinis tersering adalah nyeri, disusul dengan telinga berair. Hal ini sesuai dengan penelitian Hui yang menemukan bahwa 70\% dari penderita OE memiliki keluhan nyeri pada telinga/ otalgia. ${ }^{79}$ Nyeri ini juga menjadi salah satu tanda patogmonis OE yang membedakannya dengan Otitis Media (OM), dimana ditemukannya rasa nyeri hebat pada penekanan tragus maupun daun telinga saat ditarik maupun di dorong merupakan tanda khas dari OE. ${ }^{910}$ Hal ini juga didukung oleh penelitian dari Musa dkk. dimana keluhan terbanyak pada pasien OE merupakan otalgia dan telinga berair. Telinga berair disebabkan oleh adanya discharge yang dihasilkan dari metabolisme patogen dan reaksi inflamasi pada kulit yang terinfeksi. ${ }^{8}$ Sedangkan sensasi nyeri telinga disebabkan karena telinga luar memiliki inervasi saraf yang beragam seperti saraf kranialis V, VII, IX, dan $\times$ serta cabang dari saraf servikal 2 dan $3 .{ }^{11}$ Nyeri pada kanalis auditori eksternus dan aurikula telinga dihasilkan dari rangsangan pada saraf kranialis V, VII dan X. Nyeri telinga paling banyak disebabkan karena adanya reaksi inflamasi yang mengeluarkan setokin yang merangsang persarafan di darah sekitarnya akibat adanya perlawanan terhadap patogen yang menginfeksi. ${ }^{12}$

Penyebab tersering dari OE pada penelitian ini adalah trauma. Trauma yang dimaksudkan dalam penelitian ini merupakan trauma kulit liang telinga akibat penggunaan alat bantu pengorek telinga untuk membersihkan telinga secara berlebihan. Penelitian dari Ijaz dkk menjelaskan bahwa luka pada liang telinga akibat pembersihan telinga secara berlebihan menyebabkan kecenderungan untuk infeksi Staphilococcus aureus yang merupakan isolat tersering $(43,3 \%)$ yang ditemukan pada pasien OE. ${ }^{12}$ Destruksi pada barier proteksi di 
liang telinga akibat trauma memberikan kondisi yang sesuai untuk pertumbuhan bakteri penyebab OE. Selain itu, serumen juga memberikan peran penting dalam melindungi liang telinga dengan memproduksi $\mathrm{PH}$ asam yang menghambat pertumbuhan bakteri. Terlalu sering membersihkan telinga dapat mengurangi jumlah serumen sehingga meningkatkan risiko untuk tumbuhnya bakteri pada liang telinga. Infeksi pada liang telinga secara primer jarang terjadi karena secara fisiologis lingkungan dalam liang telinga disesuaikan untuk menyulitkan perkembangan pathogen. ${ }^{9,10}$ Penyakit sistemis yang seringkali melemahkan sistem imun juga dapat memberikan kondisi yang sesuai untuk pertumbuhan patogen penyebab OE. Pasien imunokompromais seringkali menderita OE yang disebabkan oleh infeksi jamur yang jarang ditemui pada individu normal seperti Aspergillus sp dan Candida sp. Bada beberapa populasi, OE dapat disebabkan oleh gabungan dari beberapa faktor risiko misalnya saja adanya kondisi imunokompromais bersamaan dengan kebiasaan membersihkan telinga secara berlebihan yang menyebabkan trauma pada liang telinga. Pada dasarnya semua kondisi yang menyebabkan perubahan suasana fisiologis liang telinga meningkatkan risiko patogen untuk menginvasi dan menyebabkan OE.,11,12

\section{SIMPULAN}

Pada penelitian kali ini dapat disimpulkan bahwa jenis kelamin perempuan, usia 15-49 tahun cenderung lebih banyak mengalami otitis eksterna. Gejala yang paling sering dikeluhkan adalah nyeri pada liang telinga, dan penyebab paling sering adalah akibat dari trauma gesekan liang telinga.

\section{KONFLIK KEPENTINGAN}

Penulis menyatakan tidak terdapat konflik kepentingan terkait publikasi dari penelitian ini.

\section{PENDANAAN}

Penelitian ini tidak mendapatkan bantuan dana hibah dari pemerintah maupun sektor swasta lainnya.

\section{ETIKA DALAM PENELITIAN}

Penelitian ini telah mendapatkan persetujuan dari Komite Etik Fakultas Kedokteran Universitas Udayana/RSUP Sanglah Denpasar.

\section{REFERENCES}

1. Abdullahi Mohammed, Aliyu D. 2016. Risk Factors of Acute Otitis Externa Seen in Patients in a Nigerian Tertiary Institution. Sahe Med J; 19(3): 146-149.

2. Fisher S, Tony R, Kevin G, dkk. 2008. Otitis Externa. Medical Text Edinburgh.

3. Musa TS, Benu AN, Grema US, Kirfi AM. Pattern of otitis externa in Kaduna Nigeria. Pan Afr Med J. 2015;21:165.

4. Hui C. Acute Otitis Externa. Paediatr Child Health. 2013;18(2):96-98.

5. Ijaz T, Anjum AA, Aslam S. Microbial Profiling and Risk Factors Assesment for Otitis Media and Otitis Externa. Adv Life Sci. 2014;1(4):191-196.

6. Kaimio M, Saijinoma L, Vapaavouri O. Survet of Otitis Externa in Finland. Acta Otol Scand. 2017;59:14.

7. Kim HS, Kim TH, Byun JY. Clinical Differences in Types of Otalgia. J Audiol Otol. 2017;19(1):34-38.

8. Musa TS, Bemu AM, Grema US. Pattern of Otitis Media Externa in Kaduna Nigeria. Pan Afr Med J. 2015;21:165.

9. Wingelaar TT, van Ooji PA, van Hulst RA. Otitis externa in military divers: more frequent and less harmfull than reported. Diving Hyperb Med. 2017;4(1):4-8.

10. Staap W. Characteristic of Human Ear Canal. J Acoust Soc Am. 2014;78(4):2146-2148.

11. Incidence and risk of various disorder of the ecternal ear in patients with hearing aids treated in ENT practices in Germany. Otol Neurotol. 2019;40(8):1076-1081.

12. Waitzman AA, Elluru RG, Belatine J. Otitis Externa. J Audiol Otol. 2004;8(1):21-30.

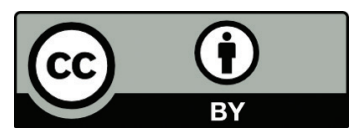

This work is licensed under a Creative Commons Attribution 